\title{
Comparison of Titanium Mesh Implants with PLA-Hydroxyapatite Coatings for Maxillofacial Cancer Reconstruction
}

\author{
S. I. Tverdokhlebov ${ }^{1, a)}$, E. L. Choinzonov², O. V. Kolokolova ${ }^{3,4, b)}$, \\ and N. V. Cherdyntseva ${ }^{2}$ \\ ${ }^{I}$ Department of Theoretical and Experimental Physics, National Research Tomsk Polytechnic University, \\ Usova Street 4A, Tomsk, 634050 Russia \\ ${ }^{2}$ Tomsk Cancer Research Institute, Kooperativny Street 5, Tomsk, 634050 Russia \\ ${ }^{3}$ Institute of Strength Physics and Materials Science SB RAS, Akademicheski Pr. 2/4, Tomsk, 634055 Russia \\ ${ }^{4}$ Technology Platform "Medicine of the Future", Science and Engineering Board "Promising medical materials", \\ Novosobornaya Square 1, Tomsk, 634040 Russia \\ a) tverd@tpu.ru \\ b) Corresponding author: o.kolokolova@bk.ru
}

\begin{abstract}
Since 2013 physics of TPU and oncologists from the TCRI with participation of the "ConMet" company (Moscow) and the "Sintel" company (Tomsk Special Economic Zone resident) have been working on the theme entitled "Development of the composite implants for reconstructive surgery of a craniofacial areas of the traumatological and oncological patients" supported with the Federal Program "R\&D, part 1.3". The goal was to develop the maxillo-facial implants on the basis of the transformable titanium mesh with PLA \& hydroxyapatite coating. According to the Contract No. 14.578.21.0031, the team of developers had to start supplying these advanced implants to the industrial partners up to 2017. This research was supported with the preliminary market researches by the ISPMS SB RAS and the TP "MF". The stages of preliminary market researches were: 1) research of the Worldwide CMF market; 2) forecasting the BRIC CMF market up to $2020 ; 3$ ) the total Russian market (epidemiology) estimation as a sum of official calculations and statistics; 4) looking for the best foreign analogue prices, comparing their and our implant properties; 5) search for the best Russian analogues; 6) the investigation of the world patent database Espacenet for the last years, and finding the owners and applicants of patents of CMF osteosynthesis plates on the basis of titanium coated with PLA \& hydroxyapatite; 7) comparison of the domestic implants, and making conclusions. Several variants of the meshes have got the equal quality with the best foreign and Russian implants. The closest analogues were titanium, polyethylene, PEEK composite meshes suited to the patient shape by the Synthes company in 2014, and the only hybrid titanium "Grey" implant with layers of gelatin, dextran, collagen, HAP \& BMP-2 was found. This implant was produced by Russian institution, and it was mentioned in the report on clinical trials by L.A. Pavlova et al., 2014 [1]. There are no manufacturers of the coated implants in Russia. The average price of the similar foreign implants varies from 12 up to $40 \$$ USA per $1 \mathrm{~cm}^{2}$. It may be concluded that our implant is of the same quality as the best Russian and foreign implants.
\end{abstract}

\section{INTRODUCTION}

The objective of this work was to carry out preliminary market research of the titanium implants with multifunctional bioactive coatings by means of comparing them with existing oncology-surgical demands. There are plenty of types of foreign implants [2]. Unfortunately, Russian implants used in federal hospitals are not usually coated, and their frequency of rejection is about 10-30\%. According to A.I. Karpov \& A.A. Bolotov from the Chelyabinsk State Medical Academy [3], the mean area of the bone defects of the head after a radical surgical treatment amounts up to $151.7 \mathrm{~cm}^{2}$. Sometimes the combined defects of a cranio-maxillo-facial (Cranio Maxillofacial Fixation or CMF) area are not compatible with a normal life of a patient, and the simultaneous plastic surgery can just save his life. 


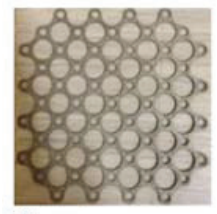

$\mathrm{Ti}$

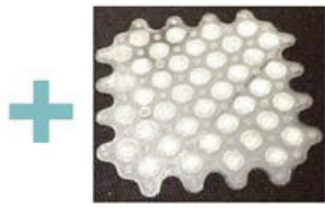

3D-printed biodegradable Biodegradable composite material composite material.

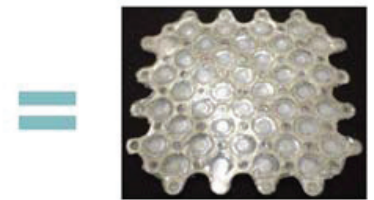

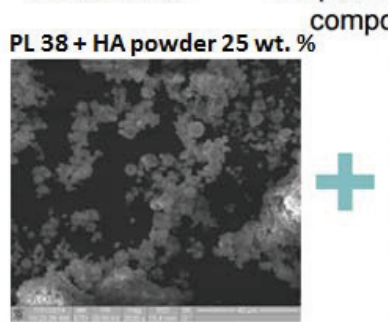
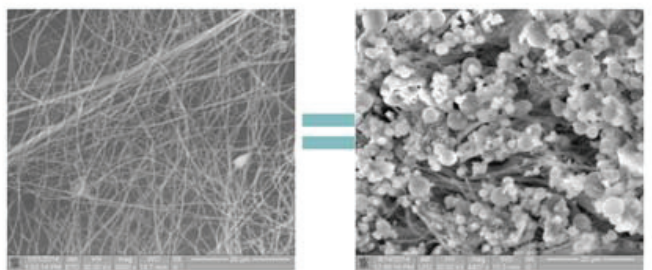

Fine CaP powders.

Biodegradable material.

\section{Biodegradable composite} material.

FIGURE 1. Stages of fabrication, composition and the final macro- and microview of the prototype

So, good composite implants are an important part for decreasing the losses of the Russian population from the oncology diseases.

The prototype of our plate coated with biodegradable materials for the reconstructive craniomaxillofacial surgery was developed by the physicists of TPU and the oncologists from the TCRI with participation of the "ConMet" company (Moscow) and the "Sintel” company (Tomsk Special Economic Zone resident).

\section{METHODOLOGY}

The stages of the preliminary market research were: 1) a survey of the Worldwide CMF market, 2) forecasting the BRIC CMF market up to 2020, 3) estimation of the total Russian market (epidemiology) as sum of official calculations and statistics, 4) looking for the best foreign analogue prices, comparison of their and our implant properties, 5) a searching for the best Russian analogues, and matching them too, 6) the mining the world patent database of the last years, and finding the owners and applicants of patents of CMF osteosynthesis plates on a basis of a titanium coated with PLA\& hydroxyapatite, 7) comparison of the domestic implants, and finally, making conclusions.
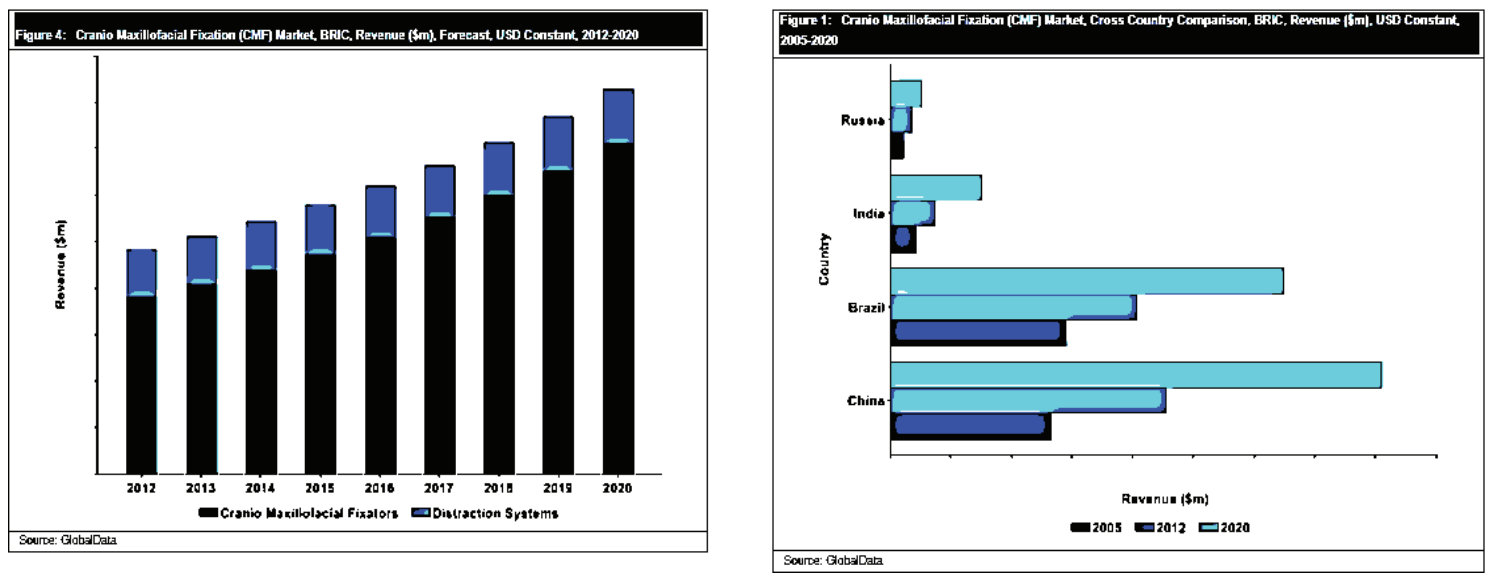

FIGURE 2. Cranio Maxillofacial Fixation (CMF) Market, BRIC ratio, Revenue (\$M), 2005-2020 [4] 


\section{Trends of the Worldwide CMF Market Up To 2020}

The Worlwide CMF market costs $\$ 5.2$ billions, CAGR $>6 \%$. Worldwide leader of 2009 was SYNTHES (43\%). Other key players of the market were Smith\&Nephew, Zimmer, DePuy, Biomet, Acumed and Orthofix, and sales of each company are more than $\$ 100$ million yearly. BRIC ratio is shown in Fig. 2.

TABLE 1. Search of the best foreign analogue prices and properties

\begin{tabular}{|c|c|c|c|c|}
\hline Producer & Title, item & $\begin{array}{l}\text { Mesh, material type, surface area } \\
\text { of CMF-implants }\end{array}$ & $\begin{array}{c}\text { Price per item } \\
\text { \$AUD } \\
(1 \$ \text { AUD }= \\
0.88 \text { USD) }\end{array}$ & $\begin{array}{l}\text { Price of } 1 \mathrm{~cm}^{2} \text { of } \\
\text { the product, } \\
\text { USDS }\end{array}$ \\
\hline \multicolumn{5}{|c|}{ Mesh of titanium and titanium alloys (titanium) } \\
\hline Surgiplas medical & $\begin{array}{l}\text { SP093 OsteoMed } \\
\text { Plating \& Fixation } \\
\text { System }\end{array}$ & $\begin{array}{l}\text { Mesh plate for the reconstruction, } \\
\text { easy/difficult moldable grid } 74 \times 50 \mathrm{~mm} \text {, } \\
\text { thickness } 0.5-0.8 \mathrm{~mm}, 26-50 \mathrm{~cm}^{2}\end{array}$ & $\$ 510$ & $\begin{array}{c}13.8 \$= \\
12.15 \mathrm{US} \$\end{array}$ \\
\hline \multicolumn{5}{|c|}{ Mesh-Non-Metal } \\
\hline $\begin{array}{l}\text { Biomet Australia } \\
\text { Pty Ltd. }\end{array}$ & $\begin{array}{l}\text { BI999 Lactosorb } \\
\text { Resorbable }\end{array}$ & $\begin{array}{l}\text { Craniofacial fixation system PGA/PLA. } \\
\text { The panel or sheet, solid or with holes } \\
\quad(0.5 \text { or } 0.8 \mathrm{~mm}) 100 \times 100 \mathrm{~mm}\end{array}$ & $\$ 1,940$ & $19.4 \$=17 \mathrm{US} \$$ \\
\hline Surgical specialties & $\begin{array}{c}\text { SQ066 CPS } \\
\text { Bioabsorbable } \\
\text { Fixation System }\end{array}$ & $\begin{array}{l}\text { System and CPS baby's plate } 1.5-2.5 \mathrm{~mm} \\
\text { mesh plates, } 14 \times 14 \text { trimethylenebis } \\
\text { polylactic acid with holes }\end{array}$ & $\$ 1,940$ & $19,4 \$=17 \mathrm{US} \$$ \\
\hline \multicolumn{5}{|c|}{ Mesh-Composite } \\
\hline $\begin{array}{l}\text { Stryker Australia } \\
\text { Pty Ltd. }\end{array}$ & $\begin{array}{c}\text { HW441 E-POR } \\
\text { Biomaterial/ Panel- } \\
\text { Porous Polyethylene } \\
\text { Titanium-Mesh } \\
\text { Composite }\end{array}$ & $\begin{array}{l}\text { Panel-porous composite of titanium and } \\
\text { polyethylene of a thickness of }>0.8 \mathrm{~mm} \text {, } \\
\qquad 76 \mathrm{~mm} \times 50 \mathrm{~mm}\end{array}$ & $\$ 1,150$ & $30.3 \$=26.7 \mathrm{US} \$$ \\
\hline \multicolumn{5}{|c|}{ Porous Polyethylene (Polymer) } \\
\hline $\begin{array}{l}\text { Medical Vision } \\
\text { Australia Plastic } \\
\text { and Cosmetic Pty } \\
\text { Ltd }\end{array}$ & $\begin{array}{l}\text { MW001 Bipore } \\
\text { Flexible Block }\end{array}$ & $\begin{array}{l}\text { Made of high density polyethylene with a } \\
\text { porous connective structure that supports } \\
\text { tissue ingrowth. The device is available in } \\
\text { various forms and can be trimmed by the } \\
\text { surgeon to meet the specific needs of the } \\
\text { patient. } 38 \times 50 \times 3 \mathrm{~mm} \text { and } 76 \times 50 \times 9 \mathrm{~mm}\end{array}$ & $\$ 825$ & $43.4 \$=38.2 \mathrm{US} \$$ \\
\hline \multicolumn{5}{|c|}{$\begin{array}{l}\text { Titanium, Polyethylene, Polyether-Ether-Ketone Complex Grid, Adjusted For Patient Forms } \\
\text { (Custom-Modeled) }\end{array}$} \\
\hline $\begin{array}{l}\text { Synthes Australia } \\
\text { Pty Ltd. }\end{array}$ & $\begin{array}{c}\text { SY772 PSI } \\
\text { Biomodelled Patient } \\
\text { Specific (PSI) }\end{array}$ & $\begin{array}{l}\text { Personal maxillofacial implant, PEEK \& } \\
\text { Titanium, } 152 \times 152 \mathrm{~mm}\end{array}$ & $\$ 9,930$ & $\begin{array}{l}42.99 \$= \\
37.8 \mathrm{US} \$\end{array}$ \\
\hline $\begin{array}{l}\text { Stryker Australia } \\
\text { Pty Ltd. }\end{array}$ & $\begin{array}{c}\text { HW433 E-POR } \\
\text { Biomaterial/ Orbital } \\
\text { Wall }\end{array}$ & $\begin{array}{l}\text { Composite mesh is made from porous } \\
\text { polyethylene and titanium coated areas of } \\
\text { the orbital walls and floor (large) } \\
41 \times 42 \mathrm{~mm} \text { thickness } 0.6-1.0 \mathrm{~mm}\end{array}$ & $\$ 985$ & $\begin{array}{c}57.95 \$= \\
50.99 \mathrm{US} \$\end{array}$ \\
\hline \multicolumn{5}{|c|}{ Our prototype } \\
\hline Our Implant & $\begin{array}{l}\text { Titanium-Mesh } \\
\text { Biocomposite }\end{array}$ & $\begin{array}{l}\quad 60 \times 50 \mathrm{~mm} \text { mesh of titanium } \\
\text { PLA \& hydroxyapatite coatings made by } \\
\text { electrospinning and plasma-spraying } \\
\text { methods }\end{array}$ & with & $7 \mathrm{US} \$$ \\
\hline
\end{tabular}




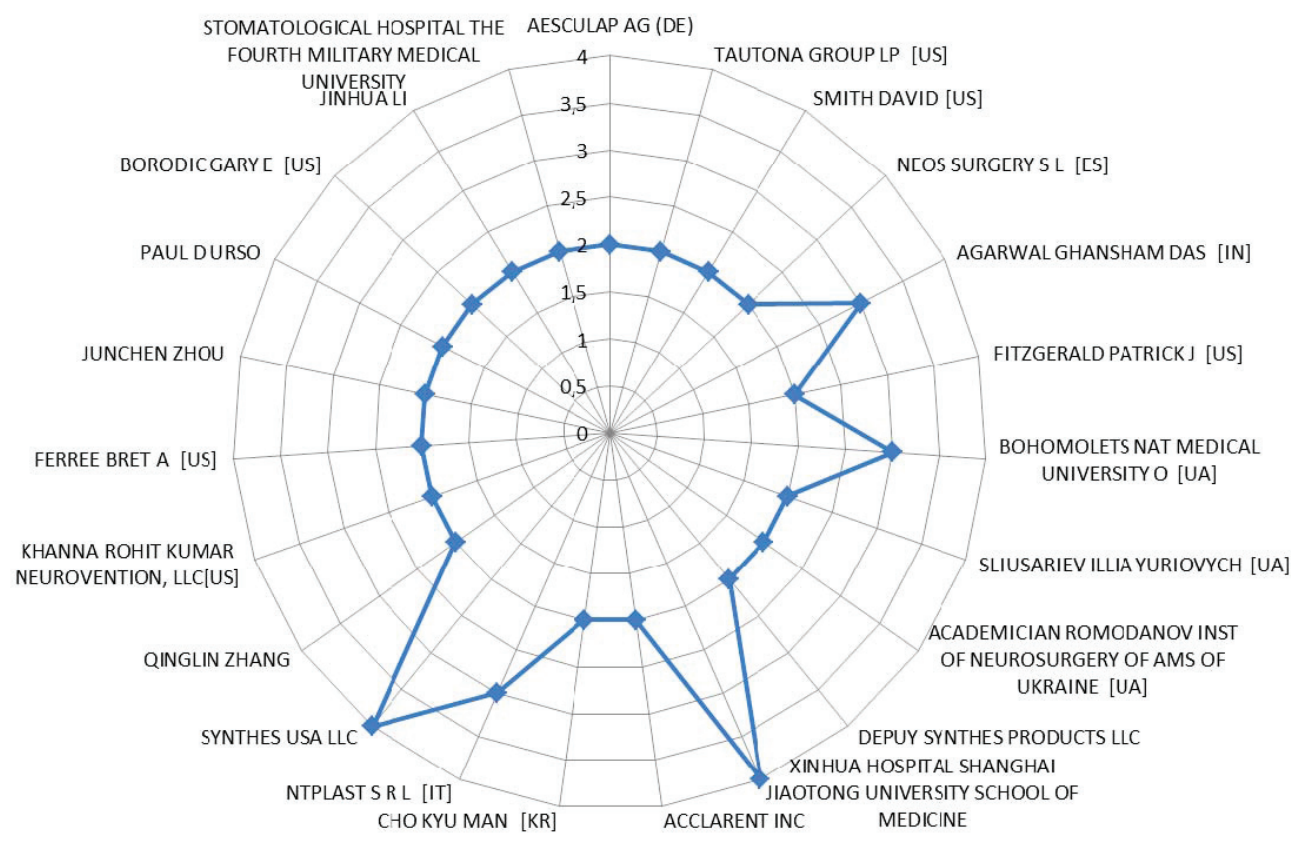

FIGURE 3. The applicants with 2 and more patents on the theme in the Espacenet database

\section{Russian Market and Epidemiology Estimations}

According to 1200 top-managers of organizations-suppliers, which are the manufacturers and buyers of orthopedic products from 15 countries, the Russian CMF market costs about dozen millions dollars of USA (according to 2016 prices). The size of the Russian market of implants can be defined of about 50 thousand units with an average price of 15-20 thousands RUB per unit (there are no official statistics).

The adult tumors of head and neck are about $20-30 \%$ of total sum. There are 50 thousands of new patients of this etiology in Russia per year [5]. The annual growth is about 2\%. There are observed 17.5 thousands/year malignant neoplasms among Russian children. Unfortunately, 10\% of all tumors malignant are maxillofacial ones among children. The need of the Russian Federation in customized CMF is about 50 thousand units/year. The frequency of rejections is from 5 up to $30 \%$ for both foreign and Russian implants.

\section{Comparison of Foreign and Our Implants Properties and Prices}

We found the best CMF analogue prices [2], which are given in Table 1.

Our plate has over 2-8-times difference in comparison with analogues prices, and the same quality, and it's a very important news for Russian hospitals due to the Euro and USD/RUB ratio rising.

\section{The Investigation of the Espacenet Data for the Last Years}

According to the Espacenet Patent Base (2010-2015), the most active companies with more than two patents of the plates for the cranio-maxillo-facial osteosynthesis or fixation on the basis of titanium alloys coated with apatite are shown in Fig. 3. The query of Espacenet was "titan AND plate AND apatite AND maxillo OR facial OR cranial in the title or abstract AND 2010-2015 as the publication date AND A61B17 as the IPC classification".

The Synthes company and the Shanghai American School of Medicine were 5-year-leaders in such patenting. Unfortunately, the Russian patent owners have not claimed the similar domestic CMF-plates. 
TABLE 2. The properties of the best russian analogues and our prototype

\begin{tabular}{lccc}
\hline \multicolumn{1}{c}{ Title and materials } & $\begin{array}{c}\text { Titanium and PEEK meshes } \\
\text { of a custom shape }\end{array}$ & $\begin{array}{c}\text { Composite or hybrid } \\
\text { titanium "Grey" implants }\end{array}$ & Our prototype \\
\hline Company or Institute & Synthes [2], 2014 & $\begin{array}{c}\text { With layers of gelatin, } \\
\text { dextran, collagen, } \\
\text { HAP \& BMP-2 [5] }\end{array}$ & $\begin{array}{c}\text { Titanium mesh with } \\
\text { PLA\&HAP coating } \\
\text { (TPU) }\end{array}$ \\
\hline Strength & +++ & +++ & +++ \\
\hline $\begin{array}{l}\text { Osteointegration due to the } \\
\text { connected porosity }\end{array}$ & ++ & +++ & +++ \\
\hline $\begin{array}{l}\text { Intraoperative shaping of the } \\
\text { implant }\end{array}$ & - & - & +++ \\
\hline Accelerated osseointegration & ++ & +++ & +++ \\
\hline Patents & +++ & + & +++ \\
\hline Cost & + & No data & ++ \\
\hline
\end{tabular}

\section{Comparison of the Implants}

Comparison of the properties of our implants with the best materials-competitors of the Russian and foreign companies is given in Table 2 .

It may be concluded that our implant is equal with the best Russian and foreign implants. Our concurrent properties are intraoperative shaping of the implant, accelerated osseointegration, and cost.

\section{CONCLUSIONS}

So, the prototype of our plate coated with biodegradable materials for the substitution of bone defects was developed by the physicists of TPU and the oncologists from the TCRI with a participation of the "ConMet" company (Moscow) and the "Sintel" company (Tomsk Special Economic Zone resident) for their applicability for the reconstructive cranio-maxillofacial surgery. The team of developers have to begin supply of these advanced implants to the industrial partners up to 2017. That is the reason why pre-marketing research is so urgent now.

We found that there is not any producer of the coated CMF-implants into Russia.

It may be concluded that the quality of our implant is equal with the best Russian and foreign implants. But the average price of the similar foreign implants varies from 12 to 40 USD per $1 \mathrm{~cm}^{2}$. Our prototype costs less than 12 USD per $1 \mathrm{~cm}^{2}$.

Worldwide leader of 2009 was SYNTHES (43\%). Also the Synthes company and the Shanghai American School of Medicine for 5 years were the leaders in the patenting of CMF. So, SYNTHES is the most active and competitive company. Our concurrent properties of the plate vs. the Synthes implants are the intraoperative shaping of the implant, accelerated osseointegration, oncological safety and cost.

The price of the one mesh plate of $60 \times 50 \times 1 \mathrm{~mm}^{3}$ on the Russian market may not exceed the price 7-10 USD per $1 \mathrm{~cm}^{2}$. Russian hospitals have the limited budget for each kind of the high technological operations with an implant application due to the medicine quota system. That is why it is the good news for Russian doctors.

It is well known that the additional layers of PLA and HAP are very good for patients. The only hybrid titanium "Grey" implant with layers of gelatin, dextran, collagen, HAP \& BMP-2 was found. This implant was introduced by Russian institution, and it was mentioned in the report on clinical trials by L.A. Pavlova et al., 2014 [1]. Nowadays these implants are not produced in Russia. We need to follow this research group to know their progress.

At the present time among the most promising bioresorbable materials for implants it is possible to choose the lactic acid and the hydroxyapatite [6]. They are used to restore the defects of bone and cartilage in clinical practice, and they were approved of by the FDA (Food and Drug Administration).

The new trend is creation of the pre-modeled products of the premium quality for the personal application. There are a few Russian oncologists interviewed, and they consider that our prototype needs a combination of the best functionality, the average price, the good personification of implants, and the preparation "by order" $[7,8]$.

Thus, our preliminary market research gave us and the producer very valuable information for the future R\&D. 


\section{ACKNOWLEDGMENTS}

This work was financially supported by the Ministry of Education and Science of the Russian Federation, Federal Target Program (agreement No. 14.578.21.0031, unique identifier RFMEFI57814X0031).

The study reported in this article was conducted according to accepted ethical guidelines involving research in humans and/or animals and was approved by an appropriate institution or national research organization.

The study is compliant with the ethical standards as currently outlined in the Declaration of Helsinki.

All individual participants discussed in this study, or for whom any identifying information or image has been presented, have freely given their informed written consent for such information and/or image to be included in the published article.

\section{REFERENCES}

1. L. A. Pavlova, Pathological anatomy of the reparative processes after implantation of nanostructured objects (experimental study), PhD Dis. Med. Sci., Moscow, 2014.

2. S. Porter, Delegate of the Minister for Health. Private Health Insurance (Prostheses), Rules 2 (2014), http:// www.comlaw.gov.au/Details/F2014L01087/Download.

3. I. A. Karpov and A. A. Bolotov, Predictive self-descriptiveness of immune system values in patients with tumors of the head and neck following reconstructive surgery, J. Ural Medical Yekaterinburg 1, 54-59 (2009).

4. BRIC Cranio Maxillofacial Fixation (CMF) Market Outlook to 2020, Global Data Corp., 2014, http:// marketpublishers.com/report/life_sciences/healthcare/bric-cranio-maxillofacial-fixation-cmf-market-outlookto-2020.html.

5. I. V. Reshetov, D. V. Shtansky, et al., Experimental trials of titanium implants having multifunctional bioactive nanostructured coatings for reconstructive craniomaxillofacial surgery and oncology, J. Annals Plastic, Reconstructive Aesthetic Surgery, 63-71 (2010).

6. Government standards for the provision of the PMF in the direction of maxillofacial surgery, Russian Medical Oncology Portal ONCOLOGY.RU, 2011, http://www.oncology.ru/specialist/treatment/standards/head-neck/.

7. A. Lee and A. Jaganathan, US Markets for Craniomaxillofacial Devices // Medtech 360. 2011. URL: http://mrg.net/Products-and-Services/Syndicated-Report.aspx?r=RPUS21CD10. (2011).

8. SYNTHES.COM, SynPOR Porous Polyethylene Implants, 2015, http://www.synthes.com/sites/NA/Products/ Biomaterials/PorousPolyethyleneImplants/Pages/porous_polyethylene_implants.aspx. 